\title{
Correction to: The Influence of Pregnancy on Female Prostate Morphophysiology in Gerbils (Meriones unguiculatus)
}

Lorranny de Jesus Gomes ${ }^{1} \cdot$ Giovanna Amaral Rodrigues ${ }^{1}$ • Barbara Costa Malmann Medeiros ${ }^{1}$.

Luana Araújo Manso ${ }^{1}$. Jordana Gomes Ramos ${ }^{1}$. Pedro Vale de Azevedo Brito ${ }^{1}$. Sebastião Roberto Taboga ${ }^{2}$. Hernandes Faustino de Carvalho ${ }^{3} \cdot$ Fernanda Cristina Alcantara dos Santos $^{1} \cdot$ Manoel Francisco Biancardi ${ }^{1}$

Published online: 5 March 2021

(C) Society for Reproductive Investigation 2021

Correction to: Reproductive Sciences https://doi.org/10.1007/s43032-021-00475-9

This article was updated to insert the unit $(\mathrm{g})$ related to the "Ovary weight" and "Adrenal weight" in Table 1.

Publisher's Note Springer Nature remains neutral with regard to jurisdictional claims in published maps and institutional affiliations.

The online version of the original article can be found at https://doi.org/ 10.1007/s43032-021-00475-9

$\triangle$ Manoel Francisco Biancardi manoel_biancardi@ufg.br

1 Department of Histology, Embryology, and Cell Biology,

Microscopy Laboratory Applied to Reproduction, Federal University of Goiás, Av. Esperança, s/n, Campus Samambaia,

Goiânia, Goiás 74690-900, Brazil

2 Department of Biology, São Paulo State University, São José do Rio Preto, São Paulo, Brazil

3 Department of Structural and Functional Biology, State University of Campinas, Campinas, São Paulo, Brazil 